\title{
Physiological and behavioral study on depressed rats model treated with Hordeum vulgare extract referenced to SSRI class
}

\author{
Kadry A. Elbakry ${ }^{1}$, Naema Ibolgasm Alazabi ${ }^{2}$, Nahed M. Omer ${ }^{3}$, Mohamed H. Bahnasawy ${ }^{4}$, \\ Omar Abdel-Hamed Ahmed-Farid ${ }^{5, *(1)}$
}

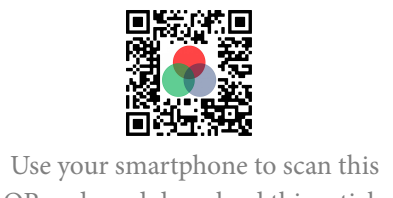

QR code and download this article

${ }^{1}$ Zoology Department, Faculty of Sciences, Damietta University, Egypt

${ }^{2}$ Department of Zoology, Faculty of Science, Al Jabal Al Gharbi University, Libya

${ }^{3}$ Histology and Histochemistry Department, Faculty of Sciences, Damietta University, Egypt

${ }^{4}$ Fish biology Department, Faculty of Sciences, Damietta University, Egypt

${ }^{5}$ Physiology Department, National Organization for Drug control and research (NODCAR) Giza, Egypt

\section{Correspondence}

Omar Abdel-Hamed Ahmed-Farid Physiology Department, National Organization for Drug control and research (NODCAR) Giza, Egypt

Email: Ebntaimya@yahoo.com

History

- Received: Apr 27, 2019

- Accepted: Aug 29, 2019

- Published: Sept 30, 2019

DOI :

https://doi.org/10.15419/bmrat.v6i9.566

\section{Check for updates}

\section{Copyright}

(๑) Biomedpress. This is an openaccess article distributed under the terms of the Creative Commons Attribution 4.0 International license.

\begin{abstract}
Objective: The aim of the present study is to investigate the effects of Hordeum vulgare aqueous extract (HVE) in a sub-chronic depression rat model. Methods: Thirty male rats were randomly divided into five groups: the first group served as a control group; the second group received i.p. injection of reserpine (Res) $(0.5 \mathrm{mg} / \mathrm{kg})$ for 20 days, the third group received i.p. injection of reserpine plus fluoxetine (Res + Flux) $(10 \mathrm{mg} / \mathrm{kg}$ p.o.) for 20 days, the fourth group received i.p. injection of Res plus HVE (1,000 mg/kg p.o.), and the fifth group received Res + Flus +HVE. Behavioral tests were measured on the 21 st day of the experiment, then rats were decapitated to determine liver function [alanine transaminase, aspartate transaminase, TP, Alb, Glob, A/G), brain monoamines and their metabolites (NE, DA, 5-HT, HVA, DOPAC, 5HIAA), oxidative and nitrositive stress markers (MDA, glutathione, oxidized glutathione, $\mathrm{NO}, \mathrm{SOD}, 8 \mathrm{OHdG}$ ) and purinergic cell capacity (ATP, ADP, AMP). Results: Obtained data showed neuro-degenerative effect of Res and deteriorative manifestation in liver function. Moreover, flux treatment showed an attenuated deterioration, manifested by Res for monoamines and its metabolites, and subsequently stabilized behaviors and decreased depression status with behavioral tests indicators. On the other hand, it showed initial indicators of liver alteration, presented by serum liver function and histological examination. In addition, treatment with HVE showed amelioration for behavioral, neurochemical functions, and decreased oxidative stress. The results were confirmed by the histological examination. Conclusion: HVE ameliorate depression induced by Res, stimulates monoamines and antioxidant status, decrease oxidonitrositive markers and increases cell energy capacity without side effects on liver, contrasting to selective serotonin re-uptake inhibitors, which produces initial indicators of liver damages.

Key words: Depression, Fluxitine, Hordeum vulgare, Rats, Resrpine
\end{abstract}

\section{INTRODUCTION}

Depression is one of the most prevalent diseases in the world. Depression is a state of complete physical malaise, which affects morbidity, general health, sleep quality and eating, and subsequently disrupts physiological and neurological homeostasis ${ }^{1}$. Causes of depression may have various sources. Depression accompanied by anxiety, which shows no clear differences between the symptoms of depression and anxiety. Bipolar depression, is accompanied by mania, a state of "high spirits", which results in increased activity and decreasing need for sleep ${ }^{2}$. The causes of depression are not known exactly, however, as with many other psychiatric illnesses, it is believed that there are several biochemical, genetical, and environmental factors that may cause depression ${ }^{3}$. There is an evidence that people who suffer from depression have physical changes in the brain. In addition, hormonal imbalance can also cause this disorder ${ }^{4}$. Some studies have shown that depression is more common in people with family members with history of the disease, encouraging researchers to seek out the genes that cause the disease ${ }^{5-7}$. Environmental factors also play a critical role in depression. Depression may occur as a result of drug addiction, certain medications, or as a result of stressful life events ${ }^{8}$. On the other hand, diseases, such as cancer, thyroid disease, and chronic pain, are associated with an increased risk of depression. Both environmental and genetic factors are likely to interact to facilitate the development of the disease in a complete and rapid manner ${ }^{9}$. Fluoxetine, an antidepressant drug, acts as a selective serotonin reuptake inhibitor (SSRI), which has better overall safety and tolerability than older antidepressants ${ }^{10}$. However, SSRIs has shown with the frequency of side effects in clinical trial data ${ }^{11}$. The most troubling adverse events seen during longterm SSRI therapy may include weight gain, sexual dysfunction, as well as sleep disturbance. In depth, SSRI improves an opportunity for more available neurotransmitters to interact with any of these receptors 
or sub-type receptors ${ }^{12}$. In addition, SSRI-induced skin reactions and gastrointestinal disturbances are the most frequently reported side effects ${ }^{13,14}$. Barley (Hordeum vulgare) is considered as one of the natural substances that can improve public health. Barley is one of the famous plants that is used in the treatment of many diseases, as it contains many nutrients (such as proteins, amino acids, dietary fiber, antioxidants, vitamins, and carbohydrates) ${ }^{15}$. Strengthening the immunity may be due to a high level of vitamin $\mathrm{C}$, which is higher in barley than orange. Barley is capable of preventing osteoporosis, since it is rich in minerals such as phosphorus, one of the most important elements for bones and teeth formation ${ }^{16}$. Chen found that barley contained vitamin E, a powerful antioxidant with the ability to cross the cerebral blood barrier ${ }^{17}$. Vitamin $\mathrm{E}$ is found in a high concentration in brain tissue and contributes to the synthesis of a number of neurotransmitters, such as dopamine. In addition, the presence of high amounts of vitamin (E) in blood stream stimulates mental functioning at all ages and protects the brain from degenerative diseases, including Alzheimer's disease and strokes. Vitamin $\mathrm{E}$ is especially important for the maintenance of older brains, which helps to reduce appearance of cerebrovascular diseases and strokes ${ }^{18}$.

The present study is aimed at examining possible protective effects of the H. vulgare extract against depression, induced by reserpine, and side effects of chemical drug (fluxitine) in a sub-chronic model of depression.

\section{METHODS}

\section{Chemicals}

2,2-Diphenyl-1-picrylhydrazyl (DPPH) Merk EC Number 217-591-8. Methanol (HPLC grade) purchased from Loba Co, India. Perchloric acid purchased from Loba Co, India. Sulphosalsilic acid and P-aminobenzyl glutamate and pyrogallol purchased from TMMEDIA Co, India. The 1,1,3,3-tetraethoxypropane, glutathione (GSH) and oxidized glutathione (GSSG) from Sigma Aldrich (USA). Potassium dichromate, monobasic potassium phosphate, nitrites and nitrate were from $\mathrm{Al}$ Nasr chemicals, Abozabal (Qualybia, Egypt). All used chemicals were either HPLC or analytical grade. Neurotransmitters and cell energy purchased from Merck (NE CAS Number: 51-41-2; DA CAS Number: 62-31-7; 5HT CAS Number: 50-67-9; ATP CAS Number: 34369-07-8; ADP CAS Number: 20398-34-9; AMP CAS Number: 4578-31-8). 8-Hydroxy-2'-deoxyguanosine sigma
CAS Number 88847-89-6. All spectrophotometer Kits were purchased from Biodiagnostic 29 El-Tahrer St.-Dokki-Giza-Egypt.

\section{Animals}

Adult male albino rats weighting about $150 \pm 15 \mathrm{~g}$ were used in the present study. Animals were kept under normal laboratory conditions in the animal house of National Organization of Drug Control and Research for 1 week before the start of the experiment. Rats were to fed according to the uniformity diet.

\section{Preparation of plant extract}

The air-dried powdered of $H$. vulgare seeds (950 g) were extracted with $30 \%$ ethanol in soxhlet apparatus for 24 hours. The extract was evaporated to dryness under reduced pressure to give approximately $7.6 \%$ w/w solid yield residues. The yield was stored at $4{ }^{\circ} \mathrm{C}$ until used.

\section{Assay of $\boldsymbol{H}$. vulgare amino acids}

Determination of $H$. vulgare amino acids seeds extract was measured and explained at Figure 1via HPLC UV detector at $254 \mathrm{~nm}$ and ammonium acetate gradient buffer, combined with acetonitril ( $\mathrm{pH}$ 5.7), according to the method of Saunders et al. ${ }^{19}$.

\section{Determination of free radical scavenging assay (DPPH)}

The radical scavenging activity of $\mathrm{HV}$ aqueous extract was determined according to the method of previous study ${ }^{20}$, described by Siddhuraju ${ }^{21}$, with different doses of extract $(50,100$, and $200 \mu \mathrm{g} / \mathrm{ml})$ at 517 $\mathrm{nm}$. The interpretation of lower absorbance indicates high free-radical scavenging activity. The respected result showed antioxidant properties of each extract, compared to rutin of the same concentration as follows: $68 \%, 79 \%, 86 \%$ for rutin and $34 \%, 48 \%, 52 \%$ for H. vulgare aqueous extract (HVE), respectively.

\section{Experimental design}

After 1 week of acclimatization period, male rats were divided randomly into five equal groups, each of six rats. Group 1 kept as control, feeding on basal diet, group 2 received reserpine i.p $(0.5 \mathrm{mg} / \mathrm{kg})$ for 20 days day other day ${ }^{22}$, group 3 received reserpine plus Fluxotine $(10 \mathrm{mg} / \mathrm{kg} \text { p.o })^{23}$ for 20 days, group 4 received reserpine plus $H$. vulgare seed $70 \%$ ethanolic extract (1,000 mg/kg p.o) for 20 days. Group 5 received reserpine plus Fluxotine and $H$. vulgare for 20 days ${ }^{24}$. Rats were grouped and housed in a conventional clean facility, according to the guidelines of the Institutional 


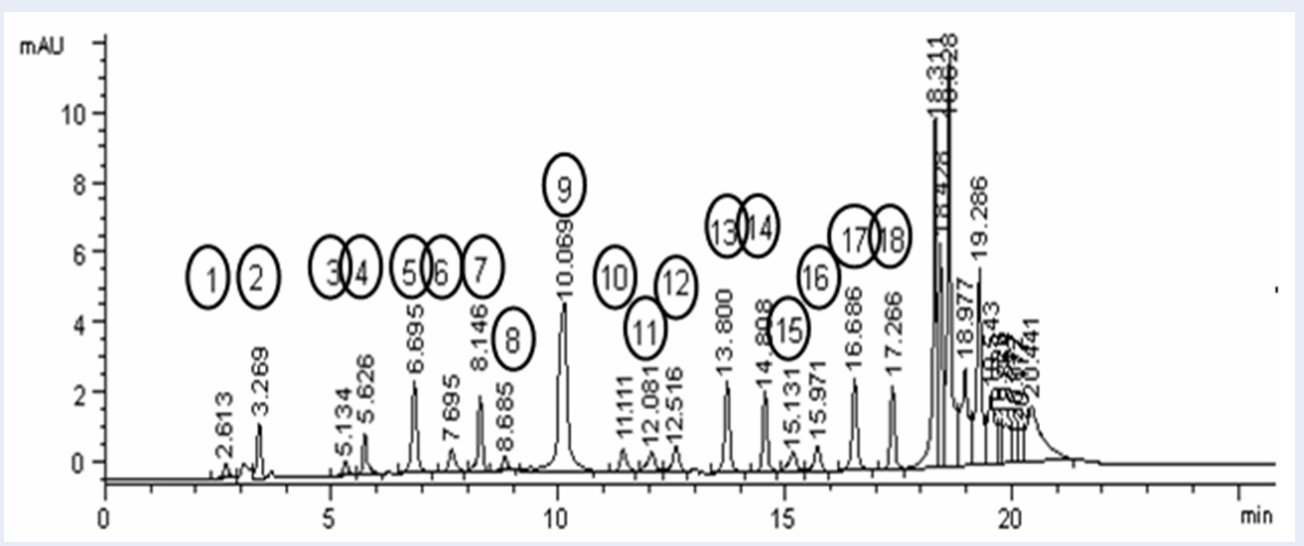

Figure 1: Amino acids constituent of Hordeum vulgare seed extract. 1- ASP: 6.21; 2- GLU: 20.8; 3- SER: 4.22; 4GLY: 4.35; 5- HIS: 2.38; 6- THR: 3.74; 7- ALA: 4.59; 8- ARG: 5.55; 9- PRO: 9.43; 10- TYR: 3.43; 11- VAL: 5.43; 12- METH: 1.75; 13- CYS: 2.69 ; 14- ILE: 3.94;15- LEU: 7.5; 16- PHYN: 5.46; 17- TRYP: 1.04; 18- LYS: 3.76.

Animal Ethics Committee of NODCAR. All the experimental procedures were carried out in accordance with international guidelines for the care and use of laboratory animals.

\section{Collection of blood samples}

At the end of the experiment, blood samples were withdrawn from the retro-orbital vein of each rat, under light anesthesia by diethyl ether, according to the method described by Moore (2000) ${ }^{25}$. Blood was allowed to coagulate and then centrifuged at 3,000 rpm for 15 minutes. The obtained serum was used to estimate the activities of liver function enzymes, total protein, total lipids, and lipid peroxidation.

\section{Preparation of brain samples}

Immediately after blood sampling, animals were sacrificed by cervical dislocation and the brain tissues were rapidly removed, washed in ice-cooled saline, plotted dray, and weighed. A weighed part of each brain was homogenized, using a homogenizer (Medical instruments, MPW-120, Poland), with ice-cooled saline $(0.9 \% \mathrm{NaCl})$ to prepare $20 \% \mathrm{w} / \mathrm{v}$ homogenate. The homogenate was then centrifuged at $4,000 \mathrm{rpm}$ for 5 minutes. The aliquot was used for the assessment of monoamines, oxidative stress markers and purenergic cell energy.

\section{Methods \\ Behavioral study}

Open field

The open field apparatus was constructed of white plywood of $72 \times 72 \mathrm{~cm}$ with $36-\mathrm{cm}$ walls. Blue lines were drawn on the floor with a marker and were visible through the clear Plexiglas floor. The lines divided the floor into sixteen $18 \times 18 \mathrm{~cm}$ squares. A central square $(18 \mathrm{~cm} \times 18 \mathrm{~cm})$ was drawn in the middle of the open field ${ }^{26}$. $70 \%$ ethyl alcohol was used to clean the open field maze for each rat to avoid odor cues. The following conditions were measured. Grooming: the duration of time, which animal spent licking or scratching while stationary. Rearing: frequency of standing on their hind legs in the maze. Center Square Duration: the duration time of rats spent in the central square. Peripheral Square Duration: the duration time of rats spent in the peripheral square. Urination: number of puddles or streaks of urine. Defecation: number of fecal pellets produced.

\section{Forced swim}

The rats were examined in a cylindrical container $(50$ $\times 20 \mathrm{~cm}$ ) filled with $30 \mathrm{~cm}$ of $22^{\circ} \mathrm{C}$ water. Generally, in this test, the water level does not let the rat rest on its tail or run away from the cylinder by climbing out. Each rat was placed in the water for 6 minutes. The time spent floating (represented immobility) was scored during the last 4 minutes. The time spent immobile was considered as an index of depression-like behavior in rodents ${ }^{27}$.

\section{Physiological study}

Determination of transaminases (AST and ALT)

Aspartate transaminase (AST) and alanine transaminase (ALT) were determined, following a colorimetric method according to Reitman and Frankel ${ }^{28}$, using reagent kit by QCA-Spain. The Principle: Aspartic 
acid $+\alpha$-ketoglutaric acid $\rightarrow$ AST Oxaloactic acid $+\mathrm{L}-$ Glutamic acid. Alanine $+\alpha$-ketoglutaric acid $\rightarrow$ ALT Pyruvic acid + L-Glutamic acid. The keto acids produced will form colored hydrazones by reaction with 2, 4-dinitrophenyl hazine.

Determination of total protein

Serum total protein evaluation was performed by the Biuret method, according to Gornall et al. ${ }^{29}$, using ready-made kits by Stanbio, Texas. The principle is that protein molecules contain a large number of peptides and bonds. When treated with copper ions in alkaline solution, a colored complex is formed between the copper, the carbonyl and amine groups of these peptides. As a similar reaction occurs with biuret, the term "biuret reaction" was adopted.

\section{Determination of albumin}

The plasma albumin was determined, using Stanbio albumin kit, purchased from Stanbio Laboratory Inc., Boerne, Texas, USA according to the method of Doumas et al. ${ }^{30}$.

\section{Determination of globulin}

The plasma globulin was calculated by subtracting albumin values from total protein of each corresponding sample. The albumin to globulin ratio $(\mathrm{A} / \mathrm{G})$ was calculated by dividing $\mathrm{A} / \mathrm{G}$ values.

Determination of the brain monoamines and metabolite concentrations by HPLC method

The HPLC system consisted of quaternary pump, a column oven, Rheodine injector, $20-\mu 1$ loop and UV variable wavelength detector. The report and chromatogram were taken from a data acquisition program, purchased from Chemstation. The sample was immediately extracted from the trace elements and lipids by the use of solid phase extraction Chromabond column NH2 phase, cat. No.730031. The sample was then injected directly into an AQUA column $150 \mathrm{~mm} 5 \mu \mathrm{C} 18$, purchased from Phenomenex, USA under the following conditions: mobile phase $20 \mathrm{mM}$ potassium phosphate, $\mathrm{pH} 2.5$, flow rate $1.5 \mathrm{ml} /$ minute, UV $270 \mathrm{~nm}^{31}$.

\section{Antioxidant parameters}

\section{Determination of brain MDA by HPLC}

MDA standard was prepared by dissolving $25 \mu \mathrm{l}$ $1,1,3,3$ tetraethoxypropane (TEP) in $100 \mathrm{ml}$ of water to get a $1 \mathrm{mM}$ stock solution. The working standard was prepared by hydrolysis of $1 \mathrm{ml}$ TEP stock solution in $50 \mathrm{ml} 1 \%$ sulfuric acid and incubated for $2 \mathrm{~h}$ at room temperature. The resulting MDA standard of 20 $\mathrm{nmol} / \mathrm{ml}$ was further diluted with $1 \%$ sulfuric acid to yield the final concentration of $1.25 \mathrm{nmol} / \mathrm{ml}$, which was used as the standard for the estimation of total $\mathrm{MDA}^{32}$.

Determination of brain GSH and GSSG by HPLC

The thiols compounds of oxidized and reduced glutathione were detected by HPLC using the previously described method ${ }^{33}$.

\section{Determination of brain nitrites and nitrates by HPLC}

Nitrites and nitrates were determined by HPLC according to the method by Papadoyannis et al. ${ }^{34}$.

\section{Determination of SOD in liver}

The activity of SOD was determined according to the method of Marklund and Marklund ${ }^{35}$.

\section{Determination of brain 8-OHDG}

Isolation and hydrolysis of brain DNA was performed as previously described by Lodovici et al. ${ }^{36}$. The hydrolyzed mixture was centrifuged, and the supernatant was injected into the HPLC. The separation of 8-OHDG was performed by a LC/Agilent 1200 series HPLC apparatus (USA), using UV detectors. For chromatographic separation, we used C18 reverse phase columns in series (Supelco, 5 pm, I.D. $0.46 \times 25$ $\mathrm{cm}$ ); the eluting solution was $\mathrm{H}_{2} \mathrm{O} / \mathrm{CH}_{2} \mathrm{OH}(85: 15$ $\mathrm{v} / \mathrm{v}$ ) with $50 \mathrm{mM} \mathrm{KH}_{3} \mathrm{PO}_{4}, \mathrm{pH} 5.5$ at a flow rate of 0.68 $\mathrm{ml} /$ minute. The UV detector was set at $245 \mathrm{~nm}^{37}$. The resulting chromatogram identified the concentration from the sample as compared to that of the standard, purchased from Sigma Aldrich.

Determination of adenosine tri-phosphate content (ATP, ADP and AMP) in brain tissues by HPLC

Rapid high performance liquid chromatography method was developed for determination of adenine nucleotides in different tissues, which was used to investigate the relation between regional blood flow and tissue contents of compounds, involved in energy metabolism under physiological and pathological conditions. The detection of ATP was performed by $\mathrm{HPLC}^{38}$.

\section{Statistical analysis}

Statistical analysis of the obtained behavioral data was performed using nonparametric statistics KruskalWallis test, followed by Mann-Whitney $U$ test. Other parameters were done using Statistical Analysis Systems Institute (SAS, 1989). Significant differences 
among means were evaluated using Duncan's Multiple Range Test. The following linear model was applied:

Yij $=\mu+\alpha \mathrm{i}+\xi_{\mathrm{ij}}$

Yij= Observation measured

$\mu=$ Overall mean

$\xi \mathrm{Ij}=$ Experimental error assumed to be randomly distributed $(\sigma 2=0)$.

\section{RESULTS}

\section{Behavioral test}

Figure 2 shows the effect of an anti-hypertensive drug (Res), which induced rat depression model, confirmed by an open field behavioral test. The test shows a decrease in rearing and duration time in the peripheral zone. In contrast, other parameters of the open field for Res group showed a significant increase in grooming, duration at central zone, urination and defecation. According to Flux, HVE and their combination, obtained results demonstrated that the depression parameters are rested to the normal condition and markedly ameliorated from Res group.

Figure 3 shows the effect of Res in the spider shape of depression induction in rat model, resembling in increasing fluting, immobility time, decreased swimming, and climbing time. On the other hand, Flux group showed strength shape for climbing on another group and amelioration for swimming time with reduction in fluting time. In the same manner, HVE and HVE, plus Flux showed a marginal amelioration of the depression condition, which resulted in increased swimming time and decreased duration of fluting, or immobility time.

\section{Liver functions}

Obtained data of Table 1 shows initial reduction in liver function and leakage of enzymes from hepatocytes after sub-chronic dose of Res, which resulted in a real increase of ALT, AST and a significant decrease of TP, comparing with the control group. In the same manner, Flux showed a similar trend for hepatocytes degradation. In contrast, HVE did not show harmful effects and ameliorated liver function to almost a normal condition. It also decreased the side effect of Flux in the combination group, compared to control group.

\section{Brain monoamines and their metabolites}

The data in Table 2 suggests a significant attrition for monoamines, compared to the control group. In contrast, the groups, treated with Flux, HVE, and their combination showed results, almost similar to the control group and significantly different from the Res group.

Figure 4 shows an excessive disturbance in metabolites of DA, such as DOPAC and HVA, serotonin, 5HIAA, resembling in decrease of DA metabolites and significant increase of 5HIAA for the Res group, comparing with the control group. In addition, the Flux and combined groups with HVE showed the recovery of all metabolites. The results were almost similar to the control group and significant different from Res group. Indeed, HVE showed amelioration of DOPAC, relative to the Res group and mild, but insignificant recovery for HVA and 5HIAA.

\section{Brain oxidative stress and neuronal cell en- ergy}

Table 3 shows a massive cell membrane degradation, presenting in more than triple level of MDA concentration compared to control group, markedly decreased endogenous antioxidant markers (GSH and SOD) and stimulated nitrositive radical and oxidation due to GSSG production. In the same manner, Flux still described with oxido-nitrositive stimulator and had no effect on antioxidant system. In contrast, the HVE mixed-treated group showed amelioration for cell membrane protective properties, which decreased MDA, GSSG, NO, and increased GSH and SOD, comparing with Res group.

Figure 4 shows a severe brain DNA degradation in Res group and subsequent Res treated with Flux in combination, compared to control group. On the other hand, HVE showed an ameliorating effect and stabilized to normal conditions DNA, with a significant decrease from the Res and Flux, but with significant differences, compared to control group.

Obtained data in Table 4 shows significant cell energy exhaustion in terms of ATP, ADP, and AMP in Res group compared to control group. In addition, there was a significant amelioration for cell energy in the brain for HVE and HVE combined with Flux treated group which ameliorate energy capacity of neurons.

\section{DISCUSSION}

Antihypertensive drugs, such as reserpine, are naturally extracted indole alkaloids, acting as a dopamine depletion agent, that inhibits several neurotransmitters ${ }^{39}$. According to a planned investigated study, Res showed identical effects of reserpine as a depressive model demonstration in behavioral tests, which increased immobility and swimming or climbing time. 
Table 1: Effect of Flux and /or HVE and their combination on serum liver function in reserpine-induced depressed rats model

\begin{tabular}{|c|c|c|c|c|c|c|}
\hline \multirow[t]{2}{*}{ Groups } & \multicolumn{6}{|c|}{ Parameters } \\
\hline & $\begin{array}{l}\text { ALT } \\
\text { IU/L }\end{array}$ & $\begin{array}{l}\text { AST } \\
\text { IU/L }\end{array}$ & $\begin{array}{l}\text { TP } \\
\text { g/dL }\end{array}$ & $\begin{array}{l}\text { Alb } \\
\text { g/dL }\end{array}$ & $\begin{array}{c}\text { Glob } \\
\text { g/dL }\end{array}$ & $\mathrm{A} / \mathrm{G}$ \\
\hline Control $(n=6)$ & $\begin{array}{c}24.85 \pm \\
0.80^{e}\end{array}$ & $\begin{array}{c}25.75 \pm \\
0.97^{e}\end{array}$ & $7.69 \pm 0.22^{a}$ & $4.29 \pm 0.13^{a}$ & $3.4 \pm 0.14^{a}$ & $1.26 \pm 0.04^{a b}$ \\
\hline $\operatorname{Res}(n=6)$ & $\begin{array}{c}49.84 \pm \\
1.57^{a}\end{array}$ & $\begin{array}{c}55.5 \pm \\
1.55^{a}\end{array}$ & $6.94 \pm 0.23^{b}$ & $3.99 \pm 0.12^{a}$ & $2.95 \pm 0.09^{b}$ & $1.35 \pm 0.04^{a}$ \\
\hline Res+Flux $(n=6)$ & $\begin{array}{c}42.89 \pm \\
1.6^{b}\end{array}$ & $\begin{array}{c}47.95 \pm \\
1.72^{b}\end{array}$ & $7.03 \pm 0.21^{b}$ & $4.11 \pm 0.13^{a}$ & $2.92 \pm 0.11^{b}$ & $1.4 \pm 0.045^{a}$ \\
\hline $\operatorname{HVE}(\mathrm{n}=6)$ & $\begin{array}{c}30.03 \pm \\
1.09^{d}\end{array}$ & $\begin{array}{c}36.58 \pm \\
1.07^{d}\end{array}$ & $7.72 \pm 0.25^{a}$ & $4.16 \pm 0.14^{a}$ & $3.62 \pm 0.11^{a}$ & $1.16 \pm 0.038^{b}$ \\
\hline $\begin{array}{l}\text { Res+Flux+HVE } \\
(n=6)\end{array}$ & $\begin{array}{c}36.95 \pm \\
1.21^{c}\end{array}$ & $\begin{array}{c}42.6 \pm \\
1.60^{c}\end{array}$ & $7.55 \pm 0.22^{a}$ & $4.07 \pm 0.12^{a}$ & $3.48 \pm 0.10^{a}$ & $1.16 \pm 0.046^{b}$ \\
\hline
\end{tabular}

Table 2: Effect of Flux and HVE and their combination on brain monoamines concentration in reserpine-induced depressed rats model

\begin{tabular}{|c|c|c|c|}
\hline \multirow[t]{2}{*}{ Groups } & \multicolumn{3}{|c|}{ Parameters } \\
\hline & NE $\mu \mathrm{g} / \mathrm{g}$ tissue & DA $\mu \mathrm{g} / \mathrm{g}$ tissue & 5HT $\mu \mathrm{g} / \mathrm{g}$ tissue \\
\hline Control (n=6) & $0.566 \pm 0.021^{a}$ & $2.41 \pm 0.094^{a}$ & $0.472 \pm 0.017^{a}$ \\
\hline $\operatorname{Res}(n=6)$ & $0.277 \pm 0.012^{d}$ & $1.19 \pm 0.033^{d}$ & $0.24 \pm 0.009^{d}$ \\
\hline Res+Flux $(n=6)$ & $0.381 \pm 0.012^{b c}$ & $1.61 \pm 0.029^{b c}$ & $0.288 \pm 0.012^{c}$ \\
\hline $\operatorname{HVE}(n=6)$ & $0.353 \pm 0.022^{c d}$ & $1.48 \pm 0.066^{c}$ & $0.314 \pm 0.014 \mathrm{~b}^{c}$ \\
\hline Res+Flux+HVE $(n=6)$ & $0.435 \pm 0.020^{b}$ & $1.74 \pm 0.078^{b}$ & $0.359 \pm 0.018^{b}$ \\
\hline
\end{tabular}

Data are expressed as Mean \pm SEM for six rats /group. ${ }^{a, b, c, d}$ means having different superscript letters in the same column differ significantly $(\mathrm{p}<0.05)$

Table 3: Effect of Flux and/or HVE on brain oxidative stress markers in reserpine-induced depressed rats model

\begin{tabular}{|c|c|c|c|c|c|}
\hline \multirow[t]{2}{*}{ Groups } & \multicolumn{4}{|c|}{ Parameters } & \multirow[b]{2}{*}{$\begin{array}{l}\text { SOD } \\
\text { U/g tissue }\end{array}$} \\
\hline & $\begin{array}{c}\text { MDA } \\
\text { nmol/g tissue }\end{array}$ & $\begin{array}{c}\text { GSH } \\
\mu \mathrm{mol} / \mathrm{g} \text { tissue }\end{array}$ & $\begin{array}{c}\text { GSSG } \\
\mu \mathrm{mol} / \mathrm{g} \text { tissue }\end{array}$ & $\begin{array}{l}\text { NO } \\
\mu \mathrm{mol} / \mathrm{g} \text { tissue }\end{array}$ & \\
\hline Control $(n=6)$ & $16.92 \pm 0.41^{e}$ & $4.003 \pm 0.26^{a}$ & $0.514 \pm 0.02^{c}$ & $0.39 \pm 0.02^{d}$ & $54.25 \pm 1.88^{a}$ \\
\hline $\operatorname{Res}(n=6)$ & $55.10 \pm 3.04^{a}$ & $1.583 \pm 0.09^{c}$ & $1.41 \pm 0.054^{a}$ & $1.03 \pm 0.08^{a}$ & $22.98 \pm 0.89^{e}$ \\
\hline Res+Flux $(n=6)$ & $33.01 \pm 1.90^{b}$ & $2.105 \pm 0.21^{b c}$ & $0.954 \pm 0.03^{a b}$ & $0.66 \pm 0.05^{b c}$ & $34.62 \pm 1.22^{d}$ \\
\hline $\operatorname{HVE}(n=6)$ & $24.95 \pm 1.74^{d}$ & $2.963 \pm 0.16^{b}$ & $0.745 \pm 0.03^{b}$ & $0.58 \pm 0.06^{c}$ & $48.62 \pm 1.71^{b}$ \\
\hline $\begin{array}{l}\text { Res+Flux+HVE } \\
(n=6)\end{array}$ & $28.716 \pm 1.65^{c}$ & $2.87 \pm 0.17^{b}$ & $0.773 \pm 0.03^{b}$ & $0.70 \pm 0.05^{b}$ & $39.65 \pm 1.45^{c}$ \\
\hline
\end{tabular}

Data are expressed as Mean \pm SEM for six rats /group. ${ }^{a, b, c, d}$ means having different superscript letters in the same column differ significantly $(\mathrm{p}<0.05)$ 


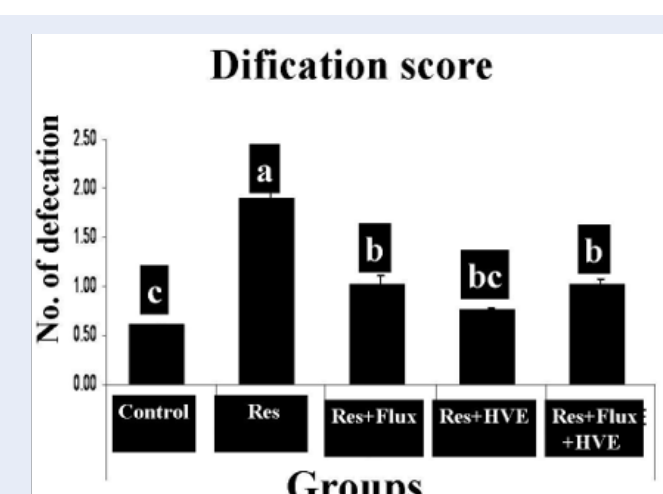

Groups

\section{Urination score}

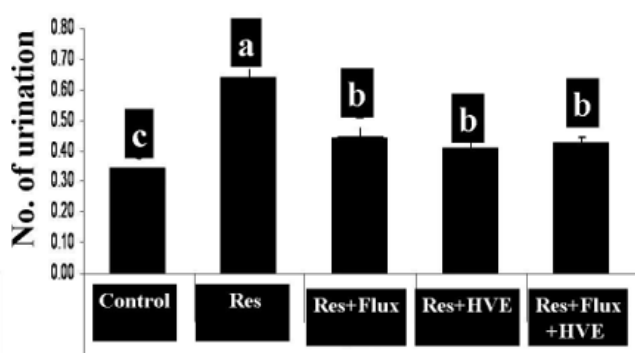

Groups

\section{Rearing}

Grooming

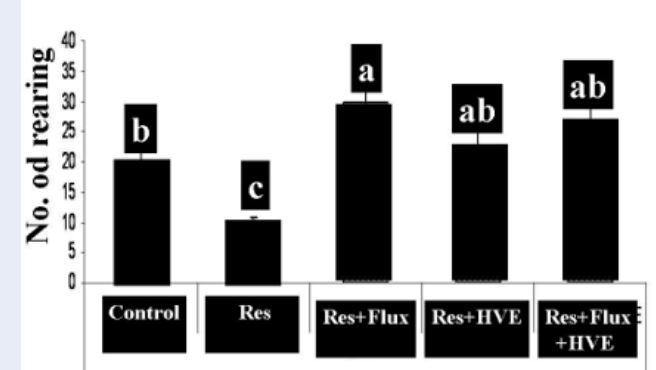

Groups

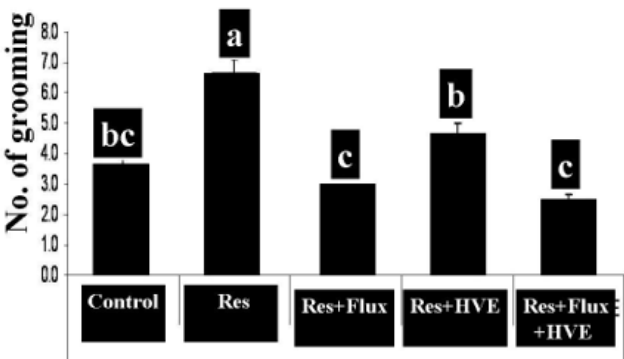

Groups

Duration in peripheral zone

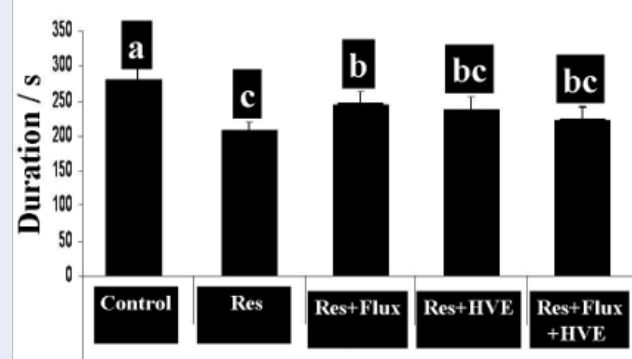

Groups

Duration in central zone

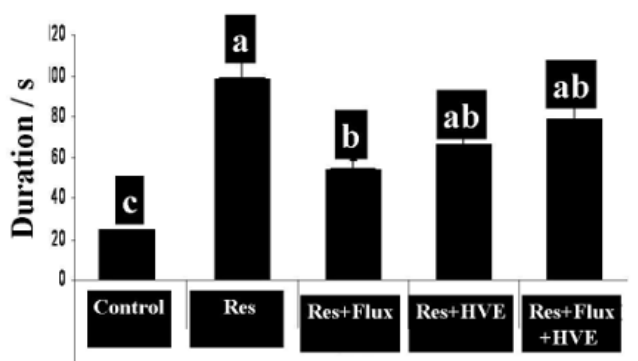

Groups

Figure 2: Effect of Flux and /or HVE on behavioral open field test in reserpine-induced depressed rats model.

Table 4: Effect of Flux and/or HVE on brain cell energy in reserpine-induced depressed rats model

\begin{tabular}{lccc}
\hline Groups & Parameters \\
\hline & ATP $\mu$ g/g tissue & ADP $\mu$ g/g tissue & AMP $\mu$ g/g tissue \\
Control (n=6) & $23.73 \pm 1.08^{a}$ & $12.68 \pm 0.74^{a}$ & $7.01 \pm 0.35^{a}$ \\
Res (n=6) & $11.47 \pm 0.26^{d}$ & $5.01 \pm 0.14^{d}$ & $3.09 \pm 0.23^{c}$ \\
Res+Flux (n=6) & $14.45 \pm 0.51^{c}$ & $7.10 \pm 0.42^{c}$ & $4.10 \pm 0.18^{c}$ \\
HVE (n=6) & $18.64 \pm 0.96^{b}$ & $10.37 \pm 0.41^{b}$ & $5.95 \pm 0.26^{b}$ \\
Res+Flux+HVE (n=6) & $17.88 \pm 0.61^{b}$ & $9.14 \pm 0.28^{b}$ & $5.16 \pm 0.22^{b}$ \\
\hline
\end{tabular}

Data are expressed as Mean \pm S.E.M for 6 rats /group. ${ }^{a, b, c, d}$ means having different superscript letters in the same column differ significantly $(\mathrm{P}<0.05)$ 


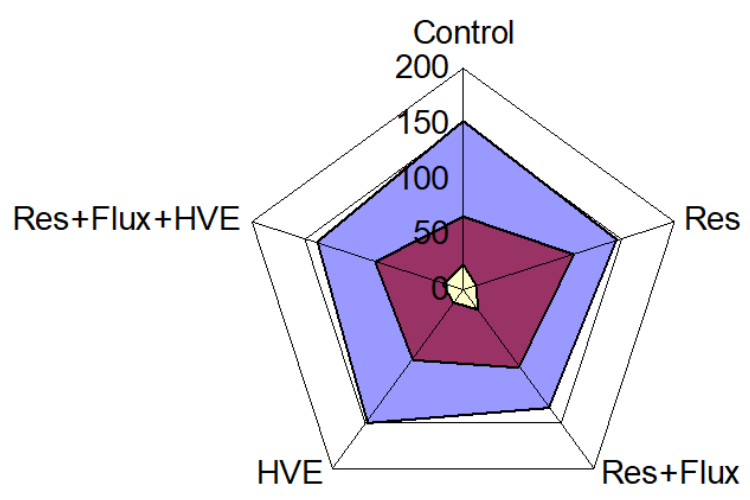

Figure 3: Effect of Flux and /or HVE on behavioral force swimming test in reserpine induced depressed rats model.
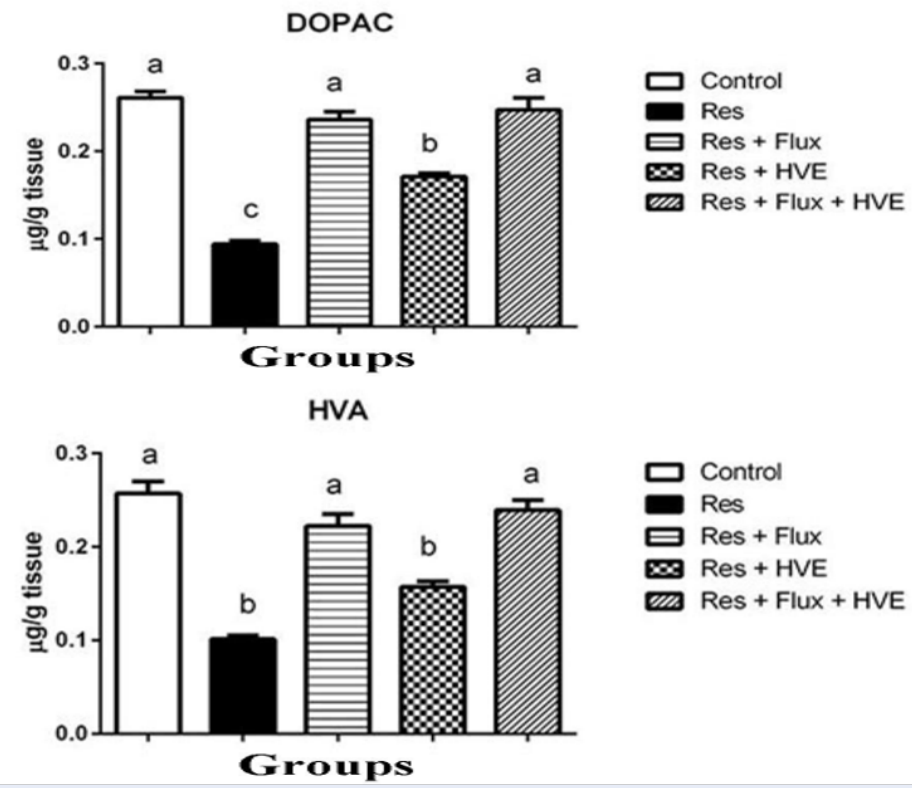

5HIAA

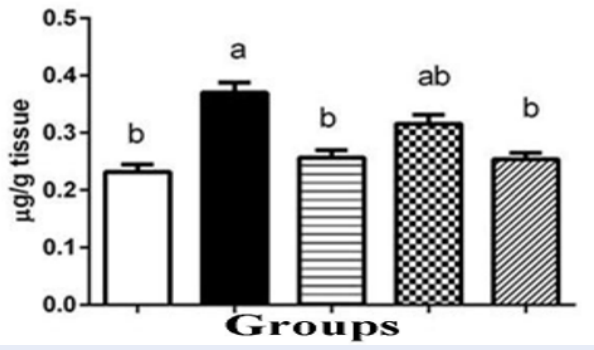

$\square$ Control
Res
$\square$ Res + Flux
Res + HVE
Res + Flux + HVE

Figure 4: Effect of Flux and/or HVE on brain monoamines concentration in reserpine induced depressed rat model. Data are expressed as Mean \pm SEM for six rats/group. $a, b, c$ means having different superscript letters in the same column differ significantly $(p<0.05)$. 
$8 \mathrm{OHdG}$

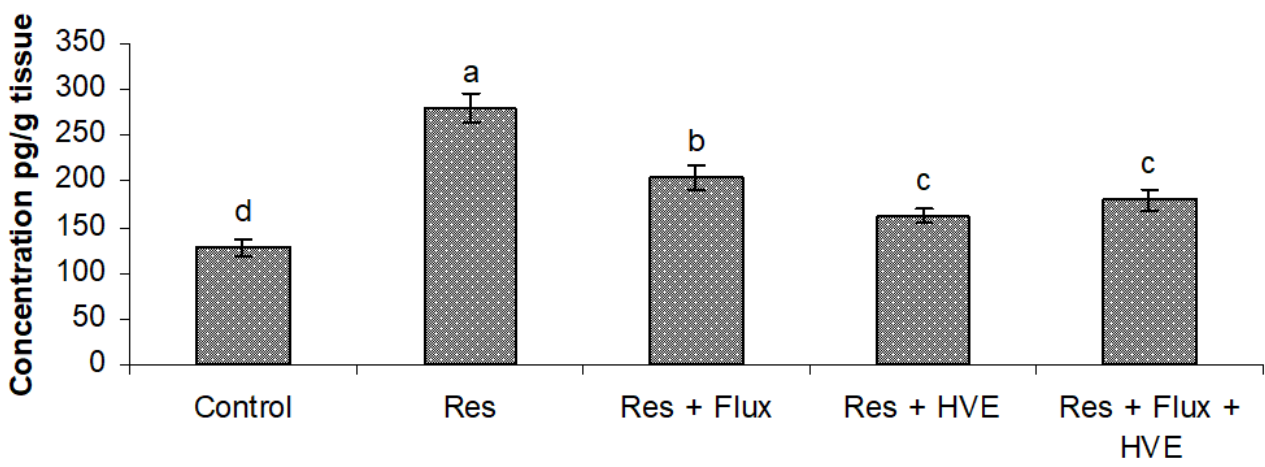

Groups

Figure 5: Effect of Flux and/or HVE on metabolite of brain DNA (8OHdG) in reserpine induced depressed rats model.

That is due to monoamines depletion. In addition, depression model was confirmed by OFT by means of increased central duration time, defecation, urination ad grooming behavior; in contrast, locomotor activity, resembling in peripheral zone and rearing time were decreased, comparing with the control group. The present finding showed that a reference drug SSRI stimulated serotonin production, stimulated locomotor activity through increasing clamping, fluting time and OFT excitatory parameters (rearing and duration of stay in peripheral zone). All the recorded results about HVE for behavioral test may bake to normal condition for each behavioral tests, but swimming time is more of a marker for normalized behavioral FST, than clamping, which reflects chemical serotonin stimulation and increased locomotor activity without abnormal excitation. These findings are in agreement with previous study of Preskorn et al. ${ }^{40}$ which proved, that the flavonoid (Resveratrol) stabilized behavioral state for Res induced depression, thus it was effective as a natural antidepressant, which may be capable of reversing the depressive-like effects of reserpine. Similarly, a combined treatment for behavioral tests showed the best treatment, which normalized swimming and decreased fluting time. Indeed, exerted beneficial effects for both herbal remedy and SSRI treatment with minor side effects. Present data showed a significant side effect for Res, which displayed toxic effects due to the indole alkaloids. The highest toxicity values of indole alkaloids were owing to tryptamine, which had the least active alkaloid and other chemicals to restrict the reason of phytotoxicity for auxins with an aromatic ring and a side chain which arise from changes of the length of the side chain and changes on the structure of the amino group. Res established a depression rat model via the decrease of all neurotransmitters and damaging liver and brain neurons. According to biochemical parameters, the Res group showed decreased level of endogenous antioxidants, increased redox status and decreased cell energy. All alterations were confirmed by histopathological examination, which reflects the evacuation and picnotic neurons and spreading neuropil in wide distribution. In the same manner, a previous study of Owens et al. ${ }^{41}$ showed that Res increases TBA, which resembles an increase in MDA concentration and decrease of GSH levels in brain and liver tissues. This could be due to the pathophysiology of multiple pathogenic factors, involved in depression and concurrent with monoaminergic depletion.

The SSRIs induced blocking the reuptake of serotonin, leading to increased concentration of the neurotransmitters in the synaptic cleft and, ultimately, to greater postsynaptic neuronal activity ${ }^{42}$. Fluoxetine and its major metabolite, norfluoxetine, are highly active against serotonin transport and also may have antimigraine effects not found with the $(R)$-enantiomer of fluoxetine ${ }^{43}$. The $(R)$-enantiomer of fluoxetine is active against serotonin transport and is shortacting $^{44}$. An increased synaptic availability of serotonin stimulates a large number of postsynaptic 5$\mathrm{HT}$ receptor types ${ }^{45}$. Stimulation of $5-\mathrm{HT}_{3}$ receptors is hypothesized to contribute to common adverse effects, including gastrointestinal and sexual dysfunction. Demonstrated data clearly concurred 
with Schatzberg ${ }^{44}$, who found that the decrease in depression adult rats, treated with Flux might be due to neuroadaptive mechanisms via monoamines stabilization. On the other hand, presented data remarked beneficial effects for Flux-treated group, but in the same way showed the prissiness of side effects, resulting in liver alteration. Due to a lower ability to metabolize serotonin and a lower capacity of glomerular filtration rate, psychotropic drugs quickly produced craniofacial malformations for embryonic rats $^{46}$. Another side effect of SSRIs, that has been evaluated in experimental studies, is the decrease in brain cell energy, especially ATP content, which was confirmed by Süzme ${ }^{47}$, who reported that fluoxetine and other SSRIs induced negative effects, which postulated bound SSRIs to sulfhydryl groups in the cell membrane and impaired ATP synthesis, by interacting with phospholipids. In the prissiness of data, liver alteration was confirmed by a histopathological examination. This fact is in agreement with Reichelt $^{48}$, who reported that the major finding of Flux treated rats was the development of hepatocellular hydropic vacuolar degeneration. Similarly, Sugimoto et al. ${ }^{49}$ examined hepatic glycogen content and confirmed that the vacuoles did not contain glycogen. Since hepatic protein contents decreased in parallel with the severity of hepatocellular vacuolar degeneration, the vacuoles were considered to be mainly associated with intracellular water accumulation. Insulin and glucagon were recently recognized as potent modulators of liver cell volume. These findings may be due to serotonin, a cause of hypoglycemia, and an increase in serum insulin levels ${ }^{50}$. Insulin stimulates $\mathrm{Na}^{+}-\mathrm{H}^{+}$exchange, $\mathrm{Na}^{+}-\mathrm{K}^{+}-2 \mathrm{Cl}$ transport, and $\mathrm{Na}^{+}-\mathrm{K}^{+}$-ATPase, and the concerted action of these transporters lead to cellular accumulation of $\mathrm{K}^{+}, \mathrm{Na}^{+}$ and $\mathrm{Cl}^{-}$and, consequently, cell swelling ${ }^{51}$. The exposure of the brain to Res induced depression and subsequent oxido-nitrisitve stress, which is a one of the most important risk factors for neurodegenerative diseases. Hordeum vulgare extract can mitigate each afore negative effect due to its contents, which is rich in flavonoids, carotenoids, vitamins, and amino acids, especially tyrosine. According to the present study, HVE showed amelioration in liver function and decreased enzyme leakage to the blood stream. In addition, a decreased brain oxido-nitrositive stress and normalized GSH and enzymatic antioxidant marker (SOD) were shown, which may be due to antioxidative properties. The obtained data are consistent with Held $^{52}$, who reported that HVE is a powerful antioxidant due to free radical scavenging activity, inhibition of lipoxygenase activity and inhibition of bcarotene co-oxidation in a linoleate model system. In the same manner, Boekema and Braun ${ }^{53}$ showed a significant decrease in MDA level whereas increase the SOD, GSH content and CAT activities with HVE, as compared to gentamicin-induced nephrotoxicity in adult male rats. According to the main active constituent of HVE for neuro-deficiency function (Tyrosine), it can be identified as a semi-essential aromatic amino acid ${ }^{54}$. It is responsible for the syntheses of catecholamines (NE and DA), thyroid hormone and melanin pigmentation ${ }^{53}$. The brain contains a large number of mitochondria and produces much energy through mitochondrial oxidative phosphorylation ${ }^{55}$. The recovery of monoamines may normalize ATP and its metabolites ADP and AMP, or mild depletion, according to the depression model, may stimulate ATP as a neuromodulator for compensating DA depletion, or monoamines deficiency. In the present study, a combination of HVE extract with Flux effects on brain neurotransmitters showed effectiveness of D2 agonist and stimulate secretion via tyrosine rich extract that precursor of DA and tryptophane of serotonin stimulant $^{56}$. The focus of obtained data was to establish the mechanism, how barley ameliorates depression via tryptophan content. It has been identified that a large percentage of tryptophan increase in brain tryptamine concentration leads to accelerated synthesis of $5-\mathrm{HT}^{57}$.

\section{CONCLUSION}

In conclusion, obtained data highlighted the vital and neural role of corrective depression, induced by reserpine with spontaneous treatment by HVE, stimulating monoamines, antioxidant status, decrease oxidonitrositive markers and increase cell energy capacity without side effects on liver. In contrast, SSRI drugs shown to induce liver damage.

\section{COMPETING INTERESTS}

None of the authors of this article have conflicting interests.

\section{AUTHORS' CONTRIBUTIONS}

All authors contributed equally in the study design, interpretation of the data, and writing of the final manuscript.

\section{REFERENCES}

1. McKeever A, Agius M, Mohr P. Review of the epidemiology of major depressive disorder and of its consequences for society and the individual. Psychiatria Danubina. 2017;29(3):222-31. PMID: 28953767. 
2. Ferrari AJ, Somerville AJ, Baxter AJ, Norman R, Patten SB, Vos T, et al. Global variation in the prevalence and incidence of major depressive disorder: a systematic review of the epidemiological literature. Psychological Medicine. 2013;43(3):471-81. PMID: 22831756. Available from: 10.1017/S0033291712001511.

3. Hyman SE. The genetics of mental illness: implications for practice. Bulletin of the World Health Organization. 2000;78(4):455-63. PMID: 10885164.

4. Simon GE. Treating depression in patients with chronic disease: recognition and treatment are crucial; depression worsens the course of a chronic illness. The Western Journal of Medicine. 2001;175(5):292-3. PMID: 11694462. Available from: 10.1136/ewjm.175.5.292.

5. Dunn EC, Brown RC, Dai Y, Rosand J, Nugent NR, Amstadter $A B$, et al. Genetic determinants of depression: recent findings and future directions. Harvard Review of Psychiatry. 2015;23(1):1-18. PMID: 25563565. Available from: 10.1097/ HRP.0000000000000054.

6. Melle I, Larsen TK, Haahr U, Friis S, Johannesen JO, Opjordsmoen S, et al. Prevention of negative symptom psychopathologies in first-episode schizophrenia: two-year effects of reducing the duration of untreated psychosis. Archives of General Psychiatry. 2008;65(6):634-40. PMID: 18519821. Available from: 10.1001/archpsyc.65.6.634.

7. Roozen HG, de Waart $R$, van der Kroft $P$. Community reinforcement and family training: an effective option to engage treatment-resistant substance-abusing individuals in treatment. Addiction (Abingdon, England). 2010;105(10):1729-38 PMID: 20626372. Available from: 10.1111/j.1360-0443.2010. 03016.x.

8. Caspi A, Sugden K, Moffitt TE, Taylor A, Craig IW, Harrington $\mathrm{H}$, et al. Influence of life stress on depression: moderation by a polymorphism in the 5-HTT gene. Science. 2003;301(5631):386-9. PMID: 12869766. Available from: 10.1126/science.1083968.

9. Patten SB. Are the Brown and Harris "vulnerability factors" risk factors for depression? Journal of Psychiatry \& Neuroscience. 1991;16(5):267-71. PMID: 1797101.

10. van der Deure WM, Appelhof BC, Peeters RP, Wiersinga WM, Wekking EM, Huyser J, et al. Polymorphisms in the brainspecific thyroid hormone transporter OATP1C1 are associated with fatigue and depression in hypothyroid patients. Clinical Endocrinology. 2008;69(5):804-11. PMID: 18410547. Available from: 10.1111/j.1365-2265.2008.03267.x.

11. Ferguson JM. Ferguson MD. SSRI antidepressant medications: adverse effects and tolerability. Primary Care Companion to the Journal of Clinical Psychiatry. 2001;3(1):22-7. PMID: 15014625. Available from: 10.4088/PCC.v03n0105.

12. Marken PA, Munro JS. Selecting a selective serotonin reuptake inhibitor: clinically important distinguishing features. Primary Care Companion to the Journal of Clinical Psychiatry. 2000;2(6):205-10. PMID: 15014630. Available from: 10.4088/ PCC.v02n0602.

13. Frasure-Smith $N$, Lespérance $F$, Juneau $M$, Talajic $M$, Bourassa MG. Gender, depression, and one-year prognosis after myocardial infarction. Psychosomatic Medicine. 1999;61(1):2637. PMID: 10024065 . Available from: 10.1097/00006842199901000-00006.

14. Goldstein BJ, Goodnick PJ. Selective serotonin reuptake inhibitors in the treatment of affective disorders, 3: tolerability, safety, and pharmacoeconomics. J Psychopharmacol . 1998;87(B):S55-87.

15. Nelson JC. Safety and tolerability of the new antidepressants. The Journal of Clinical Psychiatry. 1997;58(6):26-31. PMID: 9227670.

16. Frølich W, Aman P, Tetens I. Whole grain foods and health a Scandinavian perspective. Food \& Nutrition Re-search. 2013;57(6):57-66. PMID: 23411562. Available from: 10.3402/fnr.v57i0.18503.

17. Baik BK, Ullrich SE. Barley for food: characteristics, improvement, and renewed interest. J Cereal Sci . 2008;(48):233e42.
18. Dongowski G, Huth M, Gebhardt E, Flamme W. Dietary fiberrich barley products beneficially affect the intestinal tract of rats. The Journal of Nutrition. 2002;132(12):3704-14. PMID: 12468611. Available from: 10.1093/jn/132.12.3704.

19. Saunders JA, Saunders JM, Morris S, Wynne SA. Amino acid analysis of subcellular fractions by PITC and OPA. Chromatogram. 1988;9(1):2-4.

20. Ahmed NZ, Ahmed-Farid OA. Assessment of in-vitro and invivo bioactivities potential of some Egyptian wild plants as anti-ulcerogenic effect on male albino rats. Pharmaceutical Chemistry Journal. 2017;4(6):68-86.

21. Siddhuraju P, Becker K. The antioxidant and free radical scavenging activities of processed cowpea (Vigna unguiculata) (L.) seeds extracts. J Food Chem. 2007;101(1):10-9. Available from: 10.1016/j.foodchem.2006.01.004.

22. Ahmed RF, Abdel-Rahmana RF, Abdallaha HM, Saleha DO, Ahmed-Farid OA, Hessina AF. Antidepressant-like effect of resveratrol in a subchronic model of depression. Soc Med Res. 2014;9(2):48-53.

23. Ahmed-Farid OA, Ahmed RF, Saleh DO. Combination of resveratrol and fluoxetine in an acute model of depression in mice: Prevention of oxidative DNA fragmentation and monoamines degradation. J Appl Pharm Sci. 2016;6(6):1-7.

24. Patel R, Shah JG. Protective effect of ethanolic extract of Hordeum vulgare seed on gentamicin induced nephrotoxicity. Int Res J Pharm. 2017;8(8):1-6. Available from: 10.7897/ 2230-8407.088135.

25. Moore DM. Feldman BF, ZinkI JG, Jain NC, editors. Hematology of rabbits. Philadelphia, USA: Lippincott Williams and Wilkins; 2000.

26. Xu Y, Wang Z, You W, Zhang X, Li S, Barish PA, et al. Antidepressant-like effect of trans-resveratrol: involvement of serotonin and noradrenaline system. European Neuropsychopharmacology. 2010;20(6):405-13. PMID: 20353885 Available from: 10.1016/j.euroneuro.2010.02.013.

27. Porsolt RD, Pichon ML, Jalfre M. Depression: a new animal model sensitive to antidepressant treatments. Nature. 1977;266(5604):730-2. PMID: 559941. Available from: 10. 1038/266730a0

28. Reitman S, Frankel S. A colorimetric method for the determination of serum glutamic oxalacetic and glutamic pyruvic transaminases. American Journal of Clinical Pathology. 1957;28(1):56-63. PMID: 13458125. Available from: 10.1093/ ajcp/28.1.56.

29. Gornall AG, Bardawill CJ, David MM. Determination of serum proteins by means of the biuret reaction. The Journal of Biological Chemistry. 1949;177(2):751-66. PMID: 18110453.

30. Doumas BT, Watson WA, Biggs HG. Albumin standards and the measurement of serum albumin with bromcresol green. Clinica Chimica Acta. 1971;31(1):87-96. PMID: 5544065. Available from: 10.1016/0009-8981(71)90365-2.

31. Pagel P, Blome J, Wolf HU. High-performance liquid chromatographic separation and measurement of various biogenic compounds possibly involved in the pathomechanism of Parkinson's disease. Journal of Chromatography B, Biomedical Sciences and Applications. 2000;746(2):297-304. PMID: 11076082. Available from: 10.1016/S0378-4347(00)00348-0.

32. Karatep M. Simulatenous determination of ascorbic acid and free malondialdehyde in human serum by HPLC-UV. Chromatogr Line. 2004;12:362-5.

33. Jayatilleke E, Shaw S. A high-performance liquid chromatographic assay for reduced and oxidized glutathione in biological samples. Analytical Biochemistry. 1993;214(2):452-7. PMID: 8109733. Available from: 10.1006/abio.1993.1522.

34. Papadoyannis LN, Samanidou VF, Nitsos CC. Simultaneous determination of nitrite and nitrate in drinking water and human serum by high performance anion-exchange chromatography and UV detection. J Liq Chrom Rel Technol. 1999;22(13):2023-41. Available from: 10.1081/JLC100101783.

35. Marklund S, Marklund G. Involvement of the superoxide anion radical in the autoxidation of pyrogallol and a convenient 
assay for superoxide dismutase. European Journal of Biochemistry. 1974;47(3):469-74. PMID: 4215654. Available from: 10.1111/j.1432-1033.1974.tb03714.x.

36. Lodovici M, Casalini C, Briani C, Dolara P. Oxidative liver DNA damage in rats treated with pesticide mixtures. Toxicology. 1997;117(1):55-60. PMID: 9020199. Available from: 10.1016/ S0300-483X(96)03553-6.

37. Teerlink T, Hennekes M, Bussemaker J, Groeneveld J. Simultaneous determination of creatine compounds and adenine nucleotides in myocardial tissue by high-performance liquid chromatography. Analytical Biochemistry. 1993;214(1):27883. PMID: 8250235. Available from: 10.1006/abio.1993.1488.

38. Banchroft JD, Stevens A, Turner DR. Theory and practice of histological techniques. New York, London, San Francisco, Tokyo: Churchill Livingstone; 1996.

39. Yaffe D, Forrest LR, Schuldiner S. The ins and outs of vesicular monoamine transporters. The Journal of General Physiology. 2018;150(5):671-82. PMID: 29666153. Available from: 10.1085/jgp.201711980.

40. Preskorn SH, Ross R, Stanga CY. Selective serotonin reuptake inhibitors. In: Preskorn SH, Feighner JP, Stanga CY, Ross R, editors. Antidepressants: Past, Present and Future. vol. 157 of Handbook of Experimental Pharmacology. Berlin, Germany: Springer; 2004. p. 241-62. Available from: 10.1007/978-3-642-18500-7_9.

41. Owens JM, Knight DL, Nemeroff CB. Second generation SSRIS Human monoamine transporter binding profile of escitalopram and R-fluoxetine. Biol Psychiatry. 2002;28(4):350-5.

Available from: 10.1016/s0006-3223(01)01145-3.

42. Fuller RW, Snoddy HD, Krushinski JH, Robertson DW. Comparison of norfluoxetine enantiomers as serotonin uptake inhibitors in vivo. Neuropharmacology. 1992;31(10):997-1000. PMID: 1279447. Available from: 10.1016/0028-3908(92)901004.

43. Azmitia EC, Rubinstein VJ, Strafaci JA, Rios JC, WhitakerAzmitia PM. 5-HT1A agonist and dexamethasone reversal of para-chloroamphetamine induced loss of MAP-2 and synaptophysin immunoreactivity in adult rat brain. Brain Research. 1995;677(2):181-92. PMID: 7552242. Available from: 10.1016/ 0006-8993(95)00051-Q.

44. Schatzberg A, Cole J. Manual of clinical psychopharmacology. Washington (DC): American Psychiatric Press; 1991.

45. Shuey DL, Sadler TW, Lauder JM. Serotonin as a regulator of craniofacial morphogenesis: site specific malformations following exposure to serotonin uptake inhibitors. Teratology. 1992;46(4):367-78. PMID: 1412065. Available from: 10.1002/ tera.1420460407.

46. Reid TE, Kumar K, Wang XS. Predictive in silico studies of human 5-hydroxytryptamine receptor subtype 2B (5-HT2B) and valvular heart disease. Current Topics in Medicinal Chemistry. 2013;13(11):1353-62. PMID: 23675941. Available from: $10.2174 / 15680266113139990039$.
47. Süzme R, Gürdöl F, Deniz G, Ozden T. Response in DNA ploidy of hepatocytes to tamoxifen and/or melatonin in vivo. Research Communications in Molecular Pathology and Pharmacology. 2001;109(5-6):275-86. PMID: 12889511.

48. Reichelt ME, Mellor KM, Curl CL, Stapleton D, Delbridge LM. Myocardial glycophagy - a specific glycogen handling response to metabolic stress is accentuated in the female heart. Journal of Molecular and Cellular Cardiology. 2013;65:67-75. PMID: 24080183. Available from: 10.1016/j.yjmcc.2013.09.014

49. Sugimoto Y, Kimura I, Yamada J, Watanabe Y, Takeuchi N, Horisaka K. Effects of serotonin on blood glucose and insulin levels of glucose- and streptozotocin-treated mice. Japanese Journal of Pharmacology. 1990;54(1):93-6. PMID: 2148781 Available from: 10.1254/jip.54.93.

50. Hallbrucker C, vom Dahl S, Lang F, Gerok W, Häussinger D. Inhibition of hepatic proteolysis by insulin. Role of hormoneinduced alterations of the cellular $\mathrm{K}+$ balance. European Journal of Biochemistry. 1991;199(2):467-74. PMID: 2070798 Available from: 10.1111/j.1432-1033.1991.tb16145.x.

51. Goupy P, Hugues M, Boivin P, Amiot MJ. Antioxidant composition and activity of barley (Hordeum vulgare) and malt extracts and of isolated phenolic compounds. Journal of the Science of Food and Agriculture. 1999;79(12):162534. Available from: 10.1002/(SICI)1097-0010(199909)79: $12<1625::$ AID-JSFA411>3.0.CO;2-8.

52. Held PK. Disorders of tyrosine catabolism. Molecular Genetics and Metabolism. 2006;88(2):103-6. PMID: 16773741. Available from: 10.1016/j.ymgme.2006.04.002.

53. Boekema EJ, Braun HP. Supramolecular structure of the mitochondrial oxidative phosphorylation system. The Journal of Biological Chemistry. 2007;282(1):1-4. PMID: 17102127. Available from: 10.1074/jbc.R600031200.

54. Khan A, Schwartz KA, Kolts RL, Brown WA. BMI, sex, and antidepressant response. Journal of Affective Disorders. 2007;99(13):101-6. PMID: 17010444. Available from: 10.1016/j.jad.2006. 08.027 .

55. Mullur R, Liu YY, Brent GA. Thyroid hormone regulation of metabolism. Physiological Reviews. 2014;94(2):355-82. PMID 24692351. Available from: 10.1152/physrev.00030.2013.

56. Robinson OJ, Standing HR, DeVito EE, Cools R, Sahakian BJ. Dopamine precursor depletion improves punishment prediction during reversal learning in healthy females but not males. Psychopharmacology. 2010;211(2):187-95. PMID: 20495788. Available from: 10.1007/s00213-010-1880-1.

57. Warsh JJ, Godse DD, Stancer HC, Chan PW, Coscina DV. Brain tryptamine in rats by a new gas chromatographymas fragmentographic method. Biochemical Medicine. 1977;18(1):10-20. PMID: 901424. Available from: 10.1016/ 0006-2944(77)90045-X. 